\title{
Social and Cultural Aspects of Self-appointment in Russia*
}

\author{
BOHUSLAV ŠALANDA**
}

Sociální a kulturní aspekty ruského samozvanectví

\begin{abstract}
This essay is a study of self-appointed Czars, which is closely related to Russian political and historical traditions. In Russia, unique traditions of government existed, specific due to their use of historical references, as well as different utopias and ideals (for example a returning Czar-liberator). These are, in fact, particular symbols of power that were also present in the peasant uprisings of the Cossacks (led by Ivan Bolotnikov, Stenka Razin, Jemeljan Pugatshov and other lesser-known historical figures). On a social level, the Czar's self-appointment is one of the established forms of antifeudal protest. On a political level, it represents a struggle for power. Its religious significance must also be emphasized. The behaviour of the self-appointed Czar also contains strong elements of carnival behaviour and is thus related to fictitious emperors in folk rituals and costumes. There were several waves of Czar appointments in Russian history, as represented by Dimitri (died in 1591) and Peter III. Part of the essay focuses on a self-appointed Czar from Montenegro, the adventurer Stepan the Small, who ruled succesfully between 1767-1773. He claimed to be Czar Peter III who in actual fact had been deposed and killed in 1762 on the orders of his wife Catherine II. The following is a part of larger research project about the reception of authority and power, from a transcultural point of view.
\end{abstract}

Keywords: Self-appointed czar; Stenka Razin; Jemeljan Pugatshov; Cossaks revolted; Stepan the Small

DOI: $10.14712 / 23363525.2017 .42$

\section{Introduction}

Apart from other features Russian history is also interesting for the phenomenon of self-appointed Czars. It not only represents a part of Russian history but a part of Russian culture (including political culture) and a certain mentality: collectively shared ideas and views, certain ways of thinking. Self-appointment also became part of Russian historical and political traditions. Russia had, and still has, its specific ways of governing, which are characterised by their use of historical references. Furthermore, various utopian views gave rise to ideals [see e.g. Tshistov 2003; Pushkarev 1982; Sinicyna 1998].

Political anthropology pays attention to the symbols of state power or power symbols in various civilisations or cultural areas. It was specifically social movements, uprisings or rebellions that needed a sovereign as the symbol of power. Some leaders of such movements assumed the role of actual sovereign. A system of substitution is added, meaning the

\footnotetext{
"This study was written within the framework of the project "Homo Sociologicus Revisited" (No. 15-14478S) supported by the Czech science foundation GAČR.

** Doc. PhDr. Bohuslav Šalanda, CSc., Department of Historical Sociology, Faculty of Humanities, Charles University. U Kř́že 8, 15800 Praha 5. E-mail: bohuslav.salanda@fhs.cuni.cz.
} 
symbolic change of the seat of power (see e.g. the concept of Moscow - the third Rome) or the historical figures (the self-appointed). This question of duality in the symbolism of the Russian Baroque is the main topic ably discussed by B. A. Uspenski [1996a: 124-141].

Furthermore in Russia we find the person at the top of the power hierarchy has a special status and role. Various theoretical as well as folklore models and images participate in the creation of such status [see e.g. Tshistov 2003]. A strong Byzantine influence comes into play too. This phenomenon is additionally connected with the history of political thinking. In Russia, above all, it is important to take into account the sacralisation and deification of the monarchy [more e.g. Zhivov - Uspenski 1987].

During the Middle Ages in Russia the relationship with the monarch assumed a religious character. This feature of Russian religious thinking caught the attention of foreign visitors. All agreed that the Russians considered their sovereign to be almost equal to God or a higher deity [Zhivov - Uspenski 1987:48]. Where did this admiration of rulers come from?

The Russian religious-political thinking was directly influenced by the Byzantium. The idea of the parallel between the ruler and god came primarily from Byzantium [see e.g. Dostálová 1990: 52-53]. Sacralisation presupposes not only equality of the sovereign to God, but also the assumption of a special charisma, a special blessed gift, thanks to which he is then perceived as a supernatural being. In fact, the title "godly", "august" (teios in Greek and divus in Latin) was held by the Roman and Byzantine Caesars and members of their families beginning with Gaius Julius Caesar.

Referring to the Czar as God in the old Russian texts does not assume the identification of the czar and god or any real association between them. It refers to the parallelism between the czar and God and parallelism then underlines the endless difference between the worldly Czar and the Heavenly Czar. This claim is to a great extent based on the lack of motivation (sanctity, from the point of view of the Christian canon) of the cult of many Russian saint princes (kniazei).

The prince was more or less automatically considered a saint, acting as the necessary mediator between God and humankind and, according to the old-Russian religious-theological opinion, possessed of a special charisma. The sources referring to such tendencies are related to a later period, approximately the end of the 16th century, they may, however, portray a later, retrospective sacralisation of the Russian princes.

The Florentine Union and the fall of Byzantium brought the new element into the system of Russian religious-political ideas. Consequently, Russia remains the only orthodox state and the Russian prince is the only independent sovereign. At the same time, it is significant that the fall of Constantinople (1453) corresponds approximately to the period of the final overthrow of Tatar rule in Russia. These events unite in contemporary Russia: at the same time, when Islam won over Orthodoxy in Byzantium, Orthodoxy won over Islam in Russia. Russia takes the place of Byzantium and the Russian Great Prince takes the place of the Byzantine basileus. This fact give rise to the possibility of a new religious understanding of the Russian monarch.

The concept of Moscow as the third Rome sees the Russian Great Prince as the continuation of the Byzantine emperor. This concept had an eschatological element and in this context the Russian emperor as the head of the last Orthodox empire assumed the role of the messiah [see mainly Sinicyna 1998]. 


\section{Social and Cultural Aspects of Self-appointment in Russia}

The phenomenon of Russian self-appointment represents a certain possibility of duality. The self-appointed ruler was in fact the double of someone who held the highest position in the power and spiritual hierarchy. This double then acts as the "deputy" of God, Jesus Christ, Czar, king etc. A certain form of representation can emerge: the pretender can be a substitute for somebody else. Anthropologists may speak of the change of status and roles. Furthermore paternalism, in particular step-fatherhood, must be also taken into account.

This theme is highlighted in Pushkin's The Captain's Daughter. This novel not only portrays the uprising led by Pugatshov, but also exposes the problem of substituting a false father for the real one. This self-appointed father is above all wise, courageous and charming.

Pushkin in fact carried out intensive research in the area of self-appointment [Ovchinnikov 1985]. In The Captain's Daughter he tells the story of a young man and his faith in history. The story line is as follows: in the mid-18th century, a strict and dedicated soldier sends his son to join a garrison lost in a remote place in the steppe. In a blizzard he meets Jemeljan Pugatshov, who has not yet been revealed as the rebel. The future leader of the Cossack-peasant rebellion saves the hero of the story; in fact, he gives him life. The young man then has a dream, in which he sees a mother, who persuades him that the man is his real father. The father he has known up to now is supposedly ill and preparing for death. The young man comes to his father's deathbed. Instead he sees a happy looking man with a black beard. Although this is a dream, from this moment, Pugatshov fulfils the role of the young man's father. Once again, Pugatshov saves his life when he prevents his hanging; he also helps him get married. Pushkin then describes the execution of the self-appointed father: the double of the real father. The young man feels bereaved, although he has fared well in his own life.

The question arises: to what extent is it necessary to take into account the aesthetic attempts of people as a transformational force in history equal to other factors that shape it. Is there such a thing as the aesthetics of sonhood, a son's love for his father, the realisation that the world is under a certain unifying protection without which the aesthetic completion of the world is not possible?

This separation from the father also features in Shakespeare's Hamlet. The poisoning of the Danish Prince not only portrays a political murder and the struggle for power over a mythical Denmark but also represents a phenomenon in the spiritual history of humankind. Its aim is to break the father-son bonds and give the son a new father. Shakespeare has King Claudius, Pushkin Pugatshov, who proclaimed himself the Russian Czar Peter III.

In totalitarianism it was also required to disrupt the unity between father and son. The father was usually erased and the son had to break away from him emotionally; to renounce him. Then the second father appeared, seemingly the real, new one: the state and party father, who was worshipped by kneeling crowds. Thus, Stalin represented politics, economics and aesthetics. His countless portraits were displayed from high above, he gazed down from pedestals and his enormous statues were omnipresent. The reverse aesthetics of faith came into being. Among other factors religions also worship the ideal father. This human need for an ideal father is persistent. History always produces someone, 
who corresponds with this ideal. The real father then becomes a competition for the new messiah. The competitors can be removed, even killed etc.

Can Trotsky be pictured as the father of nations? Perhaps not, the paternal role would not have suited him. Neither Zinoviev or Bucharin had the feeling for the role that needed to be played. They also lacked an aesthetic sense. Stalin, on the contrary, assessed the aesthetics of the state fatherhood. The real fathers were then erased, one after another. The leader of the Russian and world proletariat, Lenin, did not represent this paternal type either (not even in reality). However he is buried in a special way in the mausoleum. This was so that he could be seen at all times, not just for people to be able to worship him, but also to show clearly that he had died. Stalin was probably afraid that suddenly a new Lenin could appear in Siberia. Stalin and those closest to him understood all too well the problems with self-appointment and duality.

\section{Good Czar Dimitri, leadership of Stenka Razin and Jemeljan Pugatshov etc.}

Let me introduce some more examples. The idea of self-appointment could not have just come about on its own. Certain economic, political, social-psychological etc. conditions had to exist. It was the end period of the dynasty of Ivan Kalita, the grandson of Alexander Nevski. This dynasty ruled the Moscow Empire for almost three hundred years. The demise of a dynasty is always the result of a tragedy in the history of a monarchy. (As we know from Czech history Ludvik Jagellonsky died in the battle of Mohac in 1526.) The demise of one dynasty means the ascension of another and the re-establishment of order. In Russia, however, the demise of the dynasty had incredibly destructive consequences. Self-appointment was the pervading phenomenon until the end of the 18th century. Only very few ruling systems could avoid self-appointment.

The first decades of the 17th century feature in the memories of people as the period of disorder (smuta). The conflict gradually incorporated all the then existing social groups. As to the power elite, the situation in Russia at the end of the 16th and the beginning of the 17 th century was rather hazy. The last member of the Rurik dynasty, Fiodor Ivanovic (1584-1598) was not fully stable mentally and power was in the hands of his brother-inlaw, Boris Godunov. Thanks to him, the Russian metropolitan was promoted to patriarch. At that time Russian territory extended as far as Siberia and Caucasus.

Boris Godunov became a Russian czar in 1605. He pursued well-being, business and education. He strove to bring western culture into the country. Between 1601 and 1604, Russia was being devastated by plague and famine. The overall dissatisfaction of the lower and higher social groups was fed by rumours of the strange death of the czarevitch Dimitri in 1591, for which Boris Godunov was blamed. Almost all historians admit the probability that this accusation is true, however, R. G. Skrynnikov [1983] disproves these assumptions.

The power turmoil in these times served a con man and adventurer Otriepov, who personated Dimitri (as False-Dimitri I) [see e.g. Skrynnikov 1987]. To gain the throne in Moscow, he counted on the help of the Polish aristocracy and the Catholic clergy. In 1604, with a small contingent of Polish troops, False-Dimitri I started his campaign. Aided by the peasant uprisings and thanks to the treachery of the boyars he reached Moscow after the death of Boris Godunov (1605). During the rebellions he was proclaimed czar, but his rule was unsuccessful and he was unpopular. A year later, Vasili Shuiski (1606-1610) the 
leader of boyars entered the fray and removed False-Dimitri. The battle for self-appointment was renewed once more by the arrival of a new False-Dimitri, so-called Tushinski Vor. The Polish took advantage of this and during the reign of Sigmund III they attempted to take over Russia. The defeated Shuiski died in Polish captivity. False-Dimitri II was not accepted as spontaneously as his self-appointed predecessor; he never even reached Moscow. He and his troops stayed in Tushino, which led to him being called thief of Tushino by his opponents.

This decade is also renowned for the long peasant uprising led by Ivan Bolotnikov. In 1606 , individual uprisings escalated into a full blown peasant war. Some members of the lower gentry, dissatisfied with the boyar czar, joined the rebels. One year later, the main rebel forces were destroyed and Bolotnikov was killed after the defeat of Tula. Bolotnikov belonged to those who fought for the good czar Dimitri. These changes and turmoil were greatly influenced by social dissatisfaction and the attempts of the gentry to gain power. The state of anarchy ended with the ascension of the Romanov dynasty and the expulsion of the Poles from Russia.

Among the Russian peasantry the idealising of the past attained a strong religious tone from the 17th century onwards. The foundation of absolute monarchy in Russia was to some extent connected to the attempt of the state and church hierarchy to centralise Orthodoxy with its rituals and liturgy. At the same time, the church representatives (e.g. the patriarch Nikon) attempted to gain leading positions in the political and economic system of the society. This led to dissension (Old Rites).

This dissension underwent a complex and colourful development; it split into several branches, some of which were typical for their zeal and enmity of the social and religious order of Russia of the 17th-19th century. The Cossack-peasant uprisings of Stenka Razin (1670-1671) and Jemeljan Pugatshov (1771-1774) were of the same belief, as well as certain groups of the Cossacks and some colonisation movements in the Russian North and in Siberia. The most radical groups of the dissension transformed the idea of the Antichrist into a synonym for rejecting the entire feudal society.

Idealisation of the past in the dissension and sectarian environment was usually connected to chiliastic ideas: expecting the end of the world and the millennial empire founded by the heavenly messiah. The emphasis was placed precisely on this expectation of the messiah [for more detail see Tshistov 2003].

The dissension was spreading with unbelievable speed into the Volga region and above all to the most northerly parts of Russia, the former Archangelsk and Olonec provinces. The inhabitants of Novgorod and its vicinity had created a relatively independent area. In 1666, the Solovki monastery in the White Sea stood at the head of the dissension. The Solovki defiance of monks managed to survive until January 1676. Solovki was followed by many other rebellions, which all Czars from Alexei to Peter I had to fight. Also the Pugatshov resistance during the reign of Catherine II had strong dissenting features.

At the same time as the Solovki rebellion started, the Don Cossacks revolted under the leadership of Stenka Razin. Dissension was one of the main slogans of the rebellion, which took place on the vast territory of the Volga region, from the Caspic Sea to Samara. Razin decided to campaign towards Moscow against the faithless czar, who was friendly with the Antichrist Nikon. Many songs, legends and tales describing Razin's adventures, his execution in 1671 as well as the defeat of the Solovki monastery have been preserved. 
The dissension was not ended with the defeat of Solovki, on the contrary, it was actually fuelled by it. The burning of the main initiators of the dissension at the stake: the proto-pope Avvakum, Lazar and deacon Fedor, in the Pustozersk settlement at the mouth of Petshora river in 1681 did not help either. Two or three decades later, the dissension infected the whole of Russia, from the Baltic Sea to the Pacific Ocean. Prior to his execution, Avvakum was deported near the Baykal. Dissenting settlements originated along the paths where this deported proto-pope walked. I will finish my outline of the dissension at this point. Here I will finish my outline of the dissension; we have at least briefly touched upon the ideological background of faith in just rulers, self-appointed rulers and usurpers of the throne, liberators and other true or false authorities.

\section{Specific personage of Peter III}

It is impossible to claim that any of the Czars ascended the throne, reigned in peace, brought the country to prosperity and died at an old age being respected by his family and subjects. Most of the time, rumours abounded that the Czar had been replaced as a baby, that he has no legitimate father, that someone helped him to depart from this world.

Historian, Milan Švankmajer [1970] wrote, among other things, about Russian history. His apt portrait of Catherine II is accompanied by a masterpiece study of Peter III's reign and the rebellion of the Cossack leader Jemeljan Pugatshov. Czar Peter III started his rule on December 25th, 1761; he had been predestined to do so long before during the life of the previous sovereign, Elizabeth Petrovna. Elizabeth I was Peter's aunt. However Peter ruled for just 186 days. In the early morning of July 28th, 1762 his wife, Catherine II took over the throne after a state coup. The figure of Peter III has always been viewed with some ambiguity.

Popular monarchism in Russia had various forms [ ̌̌vankmajer 1970: 85]. People in the peripheral territories of Russia, for example, used to kiss the name of Catherine II on the printed manifestoes displayed in public places. During Catherine's visit to Kazan in 1767, the muzhiks wanted to light candles in front of the czarina and lie down to make a live carpet for her to enter the city. The idea of a good czar had thus transformed to encompass the self-appointed, which was rather threatening for the ruling elite.

Nathan Eidelman [1986: 29] claims:

That is why the dead czars were resurrected as the "self-appointed" and they either proclaimed the living "self-appointed" as their sons and daughters or they killed them; the Czar himself, who did not recognize the peasant Peter III, was not seen by the self-appointed Czars as the "recognised Czar". In the end, everything was so tangled up that Pugatshov, the leader of the Cossack and peasant rebellion, who was also acting as the saved Peter III, was once in the governmental proclamations referred to as a self-appointed Czar, which almost meant a sacrilegious recognition of a Cossack as Czar.

Švankmajer [1970] gives examples of self-appointed rulers in his work about Catherine II. In 1765 a soldier Gavrila Kremniev proclaimed himself as Peter III. Five years later the role of the escaped Czar was taken over by a deserter called Czernyshev. At least five self-appointed Czars appeared within a period of several years. Usually they would have had the letter S (self-appointed) burnt into their foreheads and sent to do hard labour in Niercinsk. The case of Princess Elizabeth II, who appeared in Venice in 1774, is also often 
quoted. She claimed to have been an illegitimate child of the then ruling czarina Elisabeth I. She was invited to board a Russian boat, taken to Petrograd, where she soon died of consumption in prison. From 1772 onwards, the government began to take self-appointment very seriously due to rumours of a self-appointed czar, who appeared among the Jaic Cossacks [for more see Švankmajer 1970: 85-87]. Our aim is not to write the history of Russia. This has already been written by Czech historians which include Milan Švankmajer, Václav Veber, Zdeněk Sládek and Vladislav Moulis [1995]. Our attention is devoted only to certain periods of Russian history, where changes important for Russian statehood took place. The good Czars Ivan IV and Peter I will be dealt with in a separate study. In this case, we cannot speak directly of self-appointed usurpers and seizers of the throne. The following part of this study explores Russian self-appointment in the Balkans.

\section{Russian self-appointment on the coast of Montenegro}

The Mediterranean Sea was the main focus here. The Bosphorus and Dardanelle straits were too narrow and dangerous for the Russian navy. A small mountainous country, Montenegro, managed to resist Turkish expansion for centuries. Montenegrins were feared warriors, who were able to keep their independence despite being vastly outnumbered. The Turkish and Venetian cordons kept this country completely cut off from European politics. There is no evidence of visits by any European leaders.

However at the beginning of 1766, one suddenly appeared: the Russian Czar Peter III. The situation was particularly sensitive due to the fact that Peter III had been murdered four years earlier. As already mentioned, in July 1762 the Russian Czar was removed from power and treacherously killed by his own personal guard, part of the gentry and his own wife, Catherine Alexeievna. The Montenegrins gave the Czar a warm welcome and proclaimed him their sovereign; he went on to shape the country's fate for six years. This period represents the most significant episode of Montenegrin history and in particular Montenegrin relations with Russia.

The unknown man, who later proclaimed himself Peter III., had first appeared on the Montenegrin coast which was ruled over by Venice. The area was held by a governor with his seat in Kotor. The newcomer knew the art of healing with herbs, but was completely poor and therefore had himself hired as a farm hand by a wealthy and influential farmer, Vuk Markovic [Mylnikov 1987: 34-35]. Before this he had spent a long time travelling around Austrian and Turkish territories. It has also been stated that for some time he lived with Markovic's relative, Jurij Kustidi in the Montenegrin heartland. However most of our information about him comes from later, 1767 onwards as he had not been of interest before this.

Stepan Maly soon became known for his healing powers. He grew popular. People were amazed by his behaviour: unlike other village healers he never took money until his patients were cured. At the same time he debated with them about good, about the necessity of ending quarrels between the common people. He also successfully cured his master and thus gained his respect and admiration. In August 1767, rumours spread around villages claiming that Markovic's farm hand was not a common man. Stepan Maly neither publicly confirmed nor denied the claim that he was the Russian Czar Peter III, who had secretly escaped Russia and had come to seek peace among Montenegrins. 
People called him Stepan. He was of medium height, skinny, with long hair. Later, he was nicknamed Maly (the Small), which he did not earn for his short stature but rather for his behaviour, as he was small among the small and good among the good.

In the autumn of 1767, Stepan Maly began spreading rumours about his noble origins and events began to move unexpectedly quickly. Within a few weeks, the rumour resonated throughout the whole country and no one seemed to have any doubts. It then became necessary for the Montenegrins to formally recognise their Czar pilgrim. In October 1767, the council of elders - leaders and chieftains of tribes - met to proclaim Stepan the Czar. Then the national assembly met in Cetinje in the presence of seven thousand people. The assembly accepted the new sovereign with joy and the sovereign was finally recognised by the local metropolitan Savva. Stepan was not only proclaimed the Russian Czar, but also the ruler of Montenegro. The manifesto with this decision was handed over to Stepan on November 2nd, 1767. Until then Stepan had stayed in Maina together with his close supporters who later became his personal guards. His closest and most devoted friend, Marko Tanovic, was appointed Great Chancello in spite of his illiteracy. Slavs, but also Albanians and Greeks, started coming to Maina to pay their respects and express their allegiance to Stepan Maly.

Montenegrins, living in their brotherhoods and tribes, were not united by any state system, as the concept of a state in general did not exist in Montenegro at the time. The only rulers were church representatives, who had joint religious and secular power. They formed the only unifying factor of the country and presided over the popular assembly. Thus for the Montenegrins, Stepan Maly represented the first legally enthroned sovereign.

This raises the question: how was it possible that the behaviour of a self-appointed ruler met with such incredible success? In this case, the adventurer succeeded in being proclaimed the Czar not in his own country, as in the case of Pugatshov for example, but actually abroad. This represents a specific social-psychological feature. This con man was from the beginning to the end of his reign considered to be Czar Peter III, but at the same time his subjects referred to him as Stepan Maly, as if to admit that two different political personages were embodied in this one man. The self-appointed ruler himself supported this illusion. He used the signature Stepan Maly and this name, In God's Grace Stepan Maly, was also inscribed on his seal. The name itself, in fact, has royal connotations: "stefanos" in Greek means a wreath or crown. This was the name chosen by Serbian rulers from the dynasty of Stepan Dusan. By taking this name, Stepan Maly, a man without name or descent, also appropriated Serbian historic traditions. In the eyes of his contemporaries, however, Stepan Maly remained above all the Russian Czar.

Montenegrins also supported Stepan because they were convinced that only Russia or a connection with Russia could protect them against the Turks. The belief that Russia would provide salvation had already started spreading in Montenegro at the beginning of the 18th century. At this time, Peter I sent his emissary, Mihail Miloradovic, to Montenegro to gain Montenegrin support for the Russian campaign against Turkey. This confidence in Russian support was further sustained throughout the 18th century thanks to the annual subsidy financed by the Russian synod and treasury. Metropolitans often came for this financial aid to Petrograd, where they also purchased liturgical utensils, books, vestments, mitres and icons. The relations between Russian and Montenegrin churches were very close. 
The nameless wanderer who seized the power started changing the whole social system and established state administration. Prior to his rule, the country had no tax system, permanent army, road guards, judges or officers. Stepan Maly tried to end all quarrels and abolish blood feuds. He pushed forward centralisation and presented a thoroughly prepared system of reforms. He also attempted a census.

How did the situation develop? Montenegro started growing in strength right before the eyes of Turkey and Venice. The Turks believed he had the power to lead the Montenegrins to complete independence. In the summer of 1768, the army of Skandar pasha was sent against Montenegro, but the Russian-Turkish war, which started in the very same year, prevented this punitive campaign. The Venetians on the other hand tried to poison Stepan Maly, but without success. Gradually, this Balkan country found itself at the crossing point of three countries' interests: Venice, Turkey and Russia.

The Russian government needed to gain influence over Montenegro with a view to the impending war against Turkey in the years 1768-1774. Russia was aware of the fact that the Montenegrin uprising could employ a good deal of Turkish strength. Furthermore, Russians wanted to unmask Stepan Maly as a self-appointed ruler. Grigori Dolgoruki was charged with resolving these issues. He reached Montenegrin territory with his company in August of 1769. He managed to accuse Stepan Maly of self-appointment and imprison him. Two months later, however, Dolgoruki's situation became unmanageable. After various problems, he and his company left Cetinje and surprisingly, Dolgoruki appointed Stepan Maly as his deputy. He was released from prison and even awarded the officer's commission and uniform.

The Russian strategy that was designed to overthrow Stepan Maly, in the end actually strengthened his authority. He very quickly regained any lost prestige and once again appeared on the throne as if aided by magic powers. This adventurer undoubtedly took advantage of the Montenegrin belief that the Russian Czar had been miraculously saved. The main reason, however, was probably the support of the clergy. Stepan's best allies in Montenegro were the monks. It is difficult to judge to what extent the church had supported Stepan: whether they alone chose him and gave him a prepared programme or whether they started supporting him after he himself attempted to gain power. The clergy had come up with the idea of a unified state before the other social groups in the 18th century. The church represented the main bearer of these ideas.

The unknown adventurer could have reigned for many years had he not been stabbed by an unknown Greek in September of 1773 (probably at the order of the Skandar pasha). This brought to an end the first attempt to build a modern Montenegrin state.

\section{Conclusion}

This concludes our brief historical outline of the phenomenon of Russian self-appointment. It will be further developed with more material, connections and references to folk traditions. It is necessary to add that the peasant and urban uprisings in Western Europe usually took place in the name of heresy rather than in the name of a better sovereign. Otherwise, the behaviour of a self-appointed ruler possesses strong attributes of carnival behaviour. There is some connection to playing the ruler (king, emperor, Czar) in folk rituals and customs. These also represent a certain type of self-appointment added to the fact 
that the idea of immortality, or unfinished death, was a fixed feature in folk or elite group mentality. Some historical figures, in other words the above-average, influential people in the 17th and 18th century were characterised by the contamination of messiah-like features and functions and the functions of the Razin-type ataman. The self-appointed, atamans, so called Czar-liberators due to their function, had the tendency to consider themselves messiahs.

Let me present yet another connection: Pushkin, one of the greatest Russian poets, was also interested in the phenomenon of self-appointment [Ovchinnikov 1985]. He inspired Gogol to write Dead Souls and Controller. Thus, Eidelman [1986: 42] aptly claims:

Self-appointment is thus represented by every discrepancy between words and reality, each game with the phantoms. What are Gogol's "dead souls"? Formally, they are living people, who might have died, but are listed among the alive until the next audit. They are becoming self-appointed against their will (simply by existing in the papers) and their owners are paying to the state self-appointed sums for them. The self-appointed Napoleon Tshithsikov and the double self-appointed Captain Kopeikin, are not as surprising or unusual as many think.

Self-appointment cannot be understood as a purely Russian phenomenon. However in no other country was it as frequent or as important and specific for the history of ethnicity or state as in Russia. No one can write the history of Russia without considering this phenomenon, the roots of which have still not been satisfactorily explained. On a social level self-appointment is usually considered as one of the specific and stable forms of anti-feudal protest, on the political level it represents struggle for power. B. A. Uspenski [1996a: 142-183] also emphasises the religious aspect of self-appointment. He noted that self-appointment was connected with a specific relation to the Czar: understanding the power of the Czar as sacral power [Uspenski 1996a: 143]. The appearance of the self-appointed rulers probably highlights the beginning of the process of sacralisation of the sovereign. It must be added that self-appointed rulers did not only accept the names of specific Czars, but also acted in the names of some saints (for example Ilia - the prophet), which means that they pretended to have gained special powers from above. K. V. Tshistov, on the other hand, connects the phenomenon of self-appointment with the messiah-like ideas of the returning Czar - liberator.

This essay makes no claims to fully cover the phenomenon of Russian self-appointment. It merely provides basic information about this complex form of rule. This study is a part of a wider project: the study of the reception of authority and power from a transcultural view, which is a theme political-anthropology.

\section{Bibliography}

Dostálová, Růžena [1990]. Byzantská vzdělanost. Prague: Vyšehrad.

Ejdelman, Nathan J. [1986]. Smrt tyrana. Prague: Lidové nakladatelství.

Gumilev, Lev N. [1998]. Ot Rusi do Rosii. Moscow: Svarog i K.

Mylnikov, Alexandr S. [1987]. Legenda o russkom prince (Rusko-slavjanskije sviazi XVIII v. v mire narodnoi kultury). Leningrad: Izd. Nauka.

Ovchinnikov, Reginald V. [1985]. Nad „pugatshevskimi“stranicami Pushkina. Moscow: Izd. Nauka.

Perrie, Mauren [2003]. The Image of Ivan Terrrible in Russian Folklore. Cambridge: Cambridge University Press. 
Pushkarev, Lev N. (1982). Obshchestvenno-polititsheskaja mysl'Rosii. Vtoraja polovina XVII veka. Moscow: Izd. Nauka.

Sinicyna, Nina V. (1998). Tretij Rim. Istoki i evoljucija russkoi srednevekovoi koncepcii. Moscow: Izd. Indrik. Skrynnikov, Ruslan G. [1983]. Boris Godunov. Moscow: Izd. Nauka.

Skrynnikov, Ruslan G. [1987]. Samozvancy v Rosii v nachale XVII veka. Grigorij Otrepiov. Novosibirsk: Izd. Nauka.

Sokolova, Vera K. [1970]. Ruskije istoritcheskije predanija. Moscow: Izd. Nauka.

Švankmajer, Milan [1970]. Kateřina II. Prague: Svoboda.

Švankmajer, Milan - Veber, Václav - Sládek, Zdeněk - Moulis, Vladislav [1999]. Dějiny Ruska. Prague: Nakl. Lidové noviny.

Tchistov, Kirill V. [2003]. Russkaia narodnaia utopia (genesis i funkcii socialno-utopitsheskich legend. St. Peterburg: Izd. Dmitrii Bulanin.

Tshistiakova, Jelena V. - Solovjov, Vladimir M. [1987]. Stepan Razin i jego soratniki. Moscow: Mysl.

Uspenski, Boris A. [1996a]. Izbrannyje trudy. Tom I (Semiotika istorii + Semiotika kultury). Moscow: Izd. Shkola Jazyki ruskoi kultury.

Uspenski, Boris A. [1996b]. Izbrannyje trudy. Tom II (Jazyk i kultura). Moscow: Izd. Shkola Jazyki ruskoi kultury.

Zhivov, Viktor M. - Uspenski, Boris A. [1987]. Semioticheskije aspekty sakralizacii monarcha v Rosii. In. Jazyki kultury i problemy perevodimosti. Moscow: Nauka, pp. 47-153.

Bohuslav Šalanda from 2009 to the present day he has been working at the Department of Historical Sociology, Faculty of Humanities at Charles University. As editor in chief since 2009 he has been in charge of the trade periodical "Historical sociology. A journal of historical social sciences". During his employment at Pardubice University in 1997-2005 he established a branch of Social Anthropology directed at the study of ethnic issues. Here he also participated in complex field work projects in rural communities (Dolni Roven and Siroky Dul). In this area the study is carried out on a micro-level, observing in a concrete setting the limits and possibilities of both working and non-working activities (everyday and leisure). As a whole he has a multidisciplinary approach to his study. 